\title{
KETIADAAN ANAK LAKI-LAKI: AKANKAH MENJADI FAKTOR PENGHALANG PEMAKAIAN KONTRASEPSI?
}

\author{
Dwi Trisnani \\ Badan Pusat Statistik \\ e-mail :dtris@bps.go.id
}

\begin{abstract}
ABSTRAK
Tingkat penggunaan alat kontrasepsi (CPR) dan fertilitas (TFR) yang berbeda antar provinsi menimbulkan pertanyaan apakah ada pengaruh budaya terhadap pemakaian alat kontrasepsi modern yang merupakan program pemerintah melalui BKKBN. Perbedaaan TFR dan CPR antara Provinsi Sumatera Utara yang memperlihatkan masih tingginya TFR dan rendahnya CPR dibandingkan dengan Jawa Tengah menimbulkan dugaan bahwa hal ini terjadi karena adanya budaya yaitu sistem kekerabatan patrilineal pada Suku Batak yang merupakan suku yang dominan di Sumatera Utara. Budaya patrilineal yang memberi nilai lebih anak laki-laki menyebabkan berkurangnya keikutsertaan wanita dalam menggunakan alat kontrasepsi karena adanya keinginan untuk memiliki anak laki-laki. Penelitian ini bertujuan untuk mengetahui pengaruh komposisi jenis kelamin anak masih hidup yang dimiliki wanita terhadap penggunaan alat KB modern di Provinsi Sumatera Utara dan Jawa Tengah. Data yang digunakan adalah data dari Survei Demografi dan Kesehatan Indonesia (SDKI). Dalam studi ini, data yang digunakan adalah data cross-sectional untuk survei tahun 2017 di wilayah Sumatera Utara dan Jawa Tengah. Hasil analisis menunjukkan bahwa di Sumatera Utara wanita yang mempunyai anak laki-laki saja berpeluang lebih besar untuk memakai alat kotrasepsi modern daripada wanita yang tidak mempunyai anak laki-laki yang menunjukkan masih adanya son preference, sedangkan di Jawa Tengah komposisi jenis kelamin mempengaruhi penggunaan alat kontrasepsi.
\end{abstract}

Kata kunci:fertilitas, komposisi jenis kelamin, preferensi jenis kelamin

\begin{abstract}
Differences in levels of contraceptive use (CPR) and fertility (TFR) between provinces raise the question of whether there is a cultural influence on the use of modern contraception which is a government program through the BKKBN. The difference of TFR and CPR between North Sumatra Province which shows high TFR and low CPR compared to Central Java raises suspicion this is caused by patrilineal kinship culture in the Batak tribe which is the dominant tribe in North Sumatra. A patrilineal culture that gives more value to boy/s leads to reduced participation of women in using contraception because of the desire to have a son. This study aims to determine the effect of children sex composition on the use of modern family planning in North Sumatra and Central Java Province. The data used are data from the Indonesian Demographic and Health Survey (IDHS). In this study, the data used were cross-sectional data for the 2017 survey in North Sumatra and Central Java. In North Sumatra, the analysis showed that women who only had boys had a greater chance of using modern contraception than women who did not have boys who showed preference for boys, whereas in Central Java the sex composition does not affect contraceptive use.
\end{abstract}

Keywords: fertility, sex composition, sex preference 


\section{PENDAHULUAN}

Penduduk Indonesia pada tahun 2015 diperkirakan mencapai 257 juta dan menjadi penduduk terbesar keempat di dunia setelah China, India, dan Amerika Serikat (UN, 2015). Apabila jumlah penduduk besar tetapi berkualitas rendah, apalagi dengan pertumbuhan cepat, dipastikan akan memperlambat tercapainya tujuan pembangunan (Burhan, 2010). Oleh karena itu, pembangunan kependudukan difokuskan kepada upaya peningkatan sumber daya manusia (SDM) dengan dilandasi pengendalian jumlah penduduk.

Apabila jumlah penduduk dapat dikendalikan, maka peningkatan kualitas SDM akan semakin mungkin tercapai (Asmanedi, Simanjuntak, dan Ahsan, 2016). Pengendalian penduduk ini dilakukan dengan program Keluarga Berencana (KB) (Adioetomo, Burhan, dan Yunus, 2009). Program KB disebut sebagai soko guru dalam pembangunan manusia, karena sejak awal program KB selalu berada di garis depan dalam usaha membangun kualitas manusia Indonesia. Secara makro, program ini untuk mengendalikan kelahiran, dan secara mikro bertujuan membantu keluarga dan individu mewujudkan keluarga Indonesia yang berkualitas dan sejahtera (Burhan, 2010). Sejalan dengan Peraturan Pemerintah Republik Indonesia Nomor 87 tahun 2014 tentangPerkembangan

Kependudukan dan Pembangunan Keluarga, Keluarga Berencana dan Sistem Informasi Keluarga, program KB merupakan salah satu strategi untuk mengurangi kematian ibu khususnya ibu dengan kondisi 4T; terlalu muda melahirkan (di bawah usia 20 tahun), terlalu sering melahirkan, terlalu dekat jarak melahirkan, dan terlalu tua melahirkan (di atas 35 tahun) (Kemenkes, 2015)

Indikator keberhasilan $\mathrm{KB}$ bisa dilihat dari Contraceptive Prevalence Rate (CPR) yaitu persentase pemakaian kontrasepsi dan juga Total Fertility Rate (TFR) yaitu angka ratarata jumlah anak yang dilahirkan. Tingkat fertilitas nasional yang sebelumnya stagnan dari tahun 2002 sampai dengan 2012 di angka 2,6 menurun menjadi 2,4 anak di tahun 2017 (SDKI 2017). Walaupun mengalami penurunan, tingkat fertilitas ini belum mencapai target RPJMN 2,1 anak pada tahun 2015. Pemakaian alat/cara KB modern di antara wanita kawin meningkat dari SDKI 2002/2003 sampai dengan SDKI 2012, namun sedikit menurun pada SDKI 2017. Hasil SDKI 2017 juga menunjukkan 64 persen wanita kawin umur 15-49 tahun menggunakan suatu alat/cara KB, 57 persen memakai alat/cara KB modern dan 6 persen memakai alat/cara KB tradisional. Jika dilihat dari SDKI sebelumnya, penggunaan alat kontrasepsi modern sebesar 57,9 persen, yang artinya tidak terjadi peningkatan CPR.

Seiring berjalannya program KB, telah terjadi perubahan norma ke arah norma keluarga kecil. Jumlah anak ideal mengalami penurunan dari 3,2 pada tahun 1987 menjadi 2,7 pada wanita dan pada 2,9 pada laki-laki.

Pencanangan program KB sejak tahun 1970-an telah mengubah struktur kependudukan Indonesia. Tidak hanya menurunkan tingkat kelahiran dan laju pertumbuhan penduduk tetapi juga mengubah pandangan hidup tentang anak. Akan tetapi, kampanye yang gencar dilakukan oleh BKKBN dengan slogan "Dua anak cukup, laki-laki dan perempuan sama saja", rupanya belum diterima secara penuh oleh masyarakat, yang bisa dilihat dari 
rata-rata jumlah anak ideal pada wanita sebesar 2,7 dan pada laki-laki sebesar 2,9 yang mempunyai arti bahwa sebagian masyarakat Indonesia masih memilih untuk mempunyai anak lebih dari dua.

Perilaku yang berhubungan dengan besar, struktur, dan bentuk keluarga, misal jumlah keluarga ideal dan preferensi jenis kelamin mempengaruhi fertilitas secara tidak langsung melalui variabel antara, diantaranya kontrasepsi. Perilaku ini dipengaruhi oleh karakteristik sosial ekonomi dan budaya misalnya pendidikan, suku, agama, dan status migrasi (Freedman, 1975). Menurut Asih dan Oesman (2009) penggunaan kontrasepsi dipengaruhi faktor sosiodemografi (umur, pendidikan, pekerjaan, paritas, jumlah keinginan mempunyai anak dan status wanita), faktor lingkungan (keluarga, masyarakat, petugas), faktor program (pengetahuan tentang $\mathrm{KB}$, pengalaman menggunakan $\mathrm{KB}$ sebelumnya, informed consent, Informed choice) dan faktor sarana (ketersediaan obat atau alat kontrasepsi, tenaga pelayanan, tempat pelayanan dan biaya.

Dilihat dari TFR dan CPR per provinsi, terdapat perbedaan antara masing-masing provinsi, sehingga menimbulkan pertanyaan apakah ada pengaruh budaya yang menyebabkan perbedaan ini. Salah satu budaya yang ada di Indonesia adalah sistem kekerabatan. Sistem kekerabatan di dunia, termasuk di Indonesia pada dasarnya terbagi menjadi tiga yaitu patrilineal, matrilineal, dan bilateral. Suku Batak merupakan salah satu kelompok masyarakat yang menganut sistem kekerabatan patrilineal dan suku Minangkabau merupakan salah satu kelompok masyarakat yang menganut sistem kekerabatan matrilineal. Sedangkan suku Jawa merupakan masyarakat yang menganut sistem kekerabatan bilateral (Koentjaraningrat, 1970; Nauly, 2002). Pada budaya patrilineal kedudukan anak laki-laki menjadi hal yang penting dalam keluarga sebagai penerus keturunan, begitu juga kedudukan anak perempuan pada masyarakat matrilineal. Hal ini yang menyebabkan adanya kecenderungan untuk memiliki anak dengan jenis kelamin tertentu atau sex preference.. Bongaart (1998) mengatakan bahwa ketika menyatakan preferensi untuk ukuran keluarga tertentu, pasangan mungkin mempunyai komposisi jenis kelamin tertentu dalam pikirannya (misalnya, dua anak laki-laki atau setidaknya satu anak laki-laki dan satu anak perempuan).

Son preference masih banyak terjadi di Bangladesh, India, dan Pakistan karena alasan budaya, sosial, dan faktor ekonomi yang mempengaruhi nilai relatif dan biaya anak. Son preference biasanya menyertai budaya patriarchal, patrilineal, dan patrilokal. Budaya ini secara tradisional adalah pronatalis dan mempunyai tingkat fertilitas yang tinggi (Kabir, Islam dan Kabir, 2001).

Budaya patrilineal di Indonesia ada di suku Batak yang dari hasil SP2010 merupakan suku yang dominan di Sumatera Utara $(44,75$ persen) dan suku Jawa dengan budaya bilateral dominan di Jawa Tengah yaitu sebesar 97,72 persen (Ananta dkk, 2015). Nilai TFR di Sumatera Utara 2,9 melebihi TFR nasional, sedangkan Jawa Tengah nilai TFR di bawah nasional yaitu sebesar 2,3. Sebaliknya CPR Sumatera Utara untuk kontrasepsi modern sebesar 29,2 persen jauh lebih rendah dari nasional dimana nilai CPR 41,4 persen, sedangkan di Jawa Tengah CPR 44,3 persen.

Berdasarkan hal tersebut maka dilakukan penelitian untuk melihat 
adanya sex preference yang menurut Freedman dan Coombs (1974) salah satunya adalah dengan indikator perilaku, perilaku saat ini dan masa lalu, untuk wanita dengan sejumlah anak dan jenis kelamin yang sudah dimiliki, yaitu persentase yang memakai alat kontrasepsi saat ini. Calhoun, Nanda, Speizer, dan Jain (2013) juga menyebutkan pendekatan untuk mempelajari adanya son preference dengan cara meneliti hubungan antara komposisi jenis kelamin dalam keluarga dan perilaku fertilitas aktual, seperti KB dan fertilitas yang diinginkan.

Penelitian ini seharusnya lebih tepat dengan menggunakan data suku bangsa, akan tetapi karena keterbatasan data maka didekati dengan provinsi di mana suku tersebut merupakan suku yang dominan. Diasumsikan wanita dalam provinsi ini mempunyai perilaku yang tidak berbeda dengan suku yang dominan, karena adanya proses interaksi sosial dimana pilihan yang dibuat oleh seorang individu tergantung kepada individu lain. Menurut Manski (1993) dalam Durlauf dan Walker (2001) mengklasifikasikan tiga jenis efek sosial yaitu efek sosial endogen yang biasa disebut interaksi sosial, efek konstekstual, terjadi ketika perilaku individu dipengaruhi oleh karakteristik eksogen dari suatu kelompok dimana dia menjadi anggotanya, dan yang ketiga adalah efek korelasi yang terjadi ketika individu dalam suatu kelompok cenderung sama karena mempunyai lingkungan institusional yang sama atau mempunyai karakteristik individu yang sama. Dikatakan terjadi efek korelasi apabila rumah tangga dalam kelompok yang sama menunjukkan biaya dan keuntungan memiliki anak yang sama dan mempunyai fertilitas yang sama.
Oleh karena itu, untuk menjawab pertanyaan mengenai apakah ada indikasi sex preference di kedua provinsi ini bisa dilakukan dengan melihat hubungan antara jenis kelamin anak dengan penggunaan alat kontrasepsi modern. Jadi tujuan penelitian ini untuk mengetahui pengaruh komposisi jenis kelamin anak terhadap penggunaan alat kontrasepsi di Sumatera Utara dan Jawa Tengah.

\section{METODE PENELITIAN}

Penelitian ini merupakan penelitian kuantitatif dengan menggunakan analisis statistik deskritif dan analisis inferensial. Analisis deskriftif dilakukan dengan menggunakan tabulasi silang menggunakan distribusi persentase sebagai dasar menentukan hubungan antara variabel-variabel yang diteliti. Analisis inferensial dilakukan menggunakan regresi logistik biner yang merupakan sebuah teknik analisis untuk menjelaskan antara variabel respon yang berupa data dikotomi dengan satu set variabel penjelas (Hosmer dan Lemeshow, 2000). Secara umum persamaan model regresi logistik biner adalah sebagai berikut:

$n\left(\frac{p}{1-p}\right)=\beta_{0}+\beta_{1} X_{1}+\ldots+\beta_{k} X_{k}+\varepsilon$ $\mathrm{P}=$ peluang menggunakan alat kontrasepsi

$1-\mathrm{p}=$ peluang tidak menggunakan alat kontrasepsi

$\mathrm{Xk}=$ variabel bebas

Analisis inferensial digunakan untuk mengestimasi pengaruh variabel bebas terhadap variabel penggunaan alat kontrasepsi modern pada wanita kawin. Karena peluang untuk menggunakan alat kontrasepsi modern pada wanita kawin merupakan variabel dikotomi yang bernilai 1 jika menggunakan alat 
kontrasepsi modern dan 0 jika tidak menggunakan alat kontrasepsi modern (termasuk menggunakan alat kontrasepsi tradisional dan tidak menggunakan kontrasepsi), maka metode estimasi yang digunakan adalah model logistik biner. Analisis untuk penelitian ini menggunakan dua model yaitu model 1 untuk Provinsi Sumatera Utara dan model 2 untuk Provinsi Jawa Tengah. Data yang digunakan dalam penelitian ini adalah data hasil SDKI 2017 dengan responden Wanita Usia Subur (WUS) berusia 15-49 tahun yang mempunyai anak masih hidup di Provinsi Sumatera Utara dan Jawa Tengah.

\section{HASIL DAN PEMBAHASAN}

\section{a. Penggunaan Alat Kontrasepsi}

Terdapat perbedaan yang cukup besar pada persentase penggunaan alat/cara kontrasepsi modern di Sumatera Utara dan Jawa Tengah. Tingkat pemakaian alat/cara kontrasepsi di Jawa Tengah lebih besar dibandingkan dengan di Sumatera Utara. Di Sumatera Utara hanya separuh wanita 15-49 tahun yang sudah mempunya 2 anak atau lebih yang menggunakan alat/cara kontrasepsi modern. Di Jawa Tengah, persentase wanita 15-49 tahun yang memakai alat/cara kontrasepsi modern sudah mencapai 66 persen.

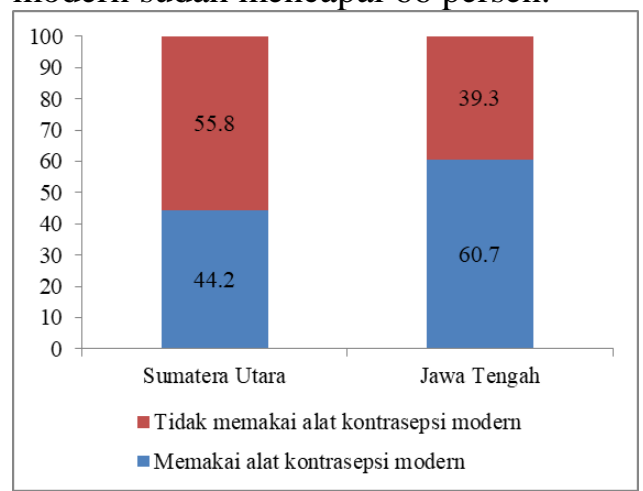

Sumber: SDKI 2017, diolah (2019)

Gambar 1. Persentase Penggunaan Alat/Cara Kontrasepsi Modern di Provinsi Sumatera Utara dan Jawa Tengah

b. Karakteristik Responden

Sebagian besar anak masih hidup yang dimiliki oleh responden baik di Sumatera Utara maupun di Jawa Tengah memiliki komposisi jenis kelamin yang sudah lengkap yaitu

Tabel 1. Karakteristik Responden di Provinsi Sumatera Utara dan Jawa Tengah

\begin{tabular}{lrrrr}
\hline & \multicolumn{3}{c}{ Sumatera Utara } & \multicolumn{2}{c}{ Jawa Tengah } \\
\cline { 2 - 5 } Variabel & $\begin{array}{c}\text { Frekuensi } \\
\text { (f) }\end{array}$ & $\begin{array}{c}\text { Persentase } \\
(\%)\end{array}$ & $\begin{array}{c}\text { Frekuensi } \\
\text { (f) }\end{array}$ & $\begin{array}{c}\text { Persentase } \\
(\%)\end{array}$ \\
\hline Komposisi Jenis Kelamin AMH & & & & \\
Laki-laki semua & 378 & 22,5 & 1.389 & 29,4 \\
Perempuan semua & 328 & 19,6 & 1.373 & 29,0 \\
Laki-laki dan perempuan & 971 & 57,9 & 1.969 & 41,6 \\
\hline Jumlah AMH & & & & \\
AMH 1 anak & 347 & 20,7 & 1.502 & 31,8 \\
AMH 2 anak & 441 & 26,3 & 2.084 & 44,1 \\
AMH 3-4anak & 701 & 41,8 & 1.060 & 22,4 \\
AMH lebih dari 4 anak & 188 & 11,2 & 84 & 1,8 \\
\hline Status Bekerja & & & & \\
Bekerja & 1.084 & 64,6 & 2.787 & 58,9 \\
Tidak Bekerja & 593 & 35,4 & 1.943 & 41,1 \\
\hline Kelompok Umur & & & & \\
15-19 tahun & 16 & 1,0 & 26 & 0,5 \\
20-34 tahun & 682 & 40,6 & 1.874 & 39,6 \\
35 tahun ke atas & 980 & 58,4 & 2.831 & 59,8 \\
\hline Keinginan Mempunyai Anak Lagi & & & & \\
Lainnya & 739 & 44,0 & 2.043 & 43,2 \\
Tidak ingin punya anak lagi & 939 & 56,0 & 2.688 & 56,6 \\
\hline Total & 1.677 & 100 & 4.731 & 100 \\
\hline
\end{tabular}


memiliki anak laki-laki dan perempuan. Bahkan, di Sumatera Utara lebih dari setengah responden mempunyai anak masih hidup dengan komposisi jenis kelamin lengkap yaitu anak laki-laki dan perempuan.

Ada perbedaan dalam hal jumlah anak masih hidup yang dimiliki responden antara di Sumatera Utara dan Jawa Tengah. Di Sumatera Utara, responden yang terbanyak memiliki 3-4 anak, akan tetapi di Jawa Tengah persentase terbesar memiliki 2 orang anak. Jumlah wanita yang memiliki anak lebih dari empat merupakan persentase terkecil di kedua provinsi. Di Sumatera Utara walaupun persentase terkecil jumlahnya masih lebih dari 10 persen, sedangkan di Jawa Tengah di bawah 2 persen.

Responden di Sumatera Utara maupun di Jawa Tengah sebagian merupakan wanita yang bekerja, walaupun secara persentase lebih banyak di Sumatera Utara. Hal ini menunjukkan partisipasi wanita kawin dalam angkatan kerja cukup besar.

Sebagian besar wanita yang mempunyai anak berumur 35 tahun atas. Persentase wanita yang berumur 15-19 tahun sangat kecil di kedua provinsi yaitu hanya 1 persen di Sumatera Utara, bahkan di Jawa Tengah hanya 0,5 persen. Menurut Musdalifah dkk (2013) umur adalah salah satu penentu perilaku termasuk dalam pemakaian kontrasepsi dan mempunyai hubungan yang signifikan dengan pemakaian alat kontrasepsi dan juga terkait dengan kesehatan reproduksi.

Nampaknya, di kedua provinsi, lebih dari separuh wanita yang sudah mempunyai anak tidak menginginkan anak lagi. Persentase responden yang tidak menginginkan anak lagi lebih besar dari pada yang lainnya, termasuk di sini yang menginginkan anak baik dalam waktu sebelum maupun sesudah 2 tahun, menginginkan anak lagi tetapi dalam waktu yang belum ditentukan, tidak bisa memutuskan apakah ingin mempunyai anak lagi, wanita yang sudah disterilisasi, maupun yang dinyatakan tidak subur. Menurut Sumartini (2016) terdapat hubungan bermakna antara keinginan mempunyai anak lagi dengan penggunaan metode kontrasepsi jangka panjang.

c. Pola dan Perbedaan Penggunaan Alat Kontrasepsi Modern menurut Karakteristik Responden.

Penggunaan alat kontrasepsi modern di Jawa Tengah jauh lebih besar daripada di Sumatera Utara untuk semua karakteristik wanita. Jika dilihat menurut komposisi jenis kelamin anak yang dimiliki, pada Tabel 2 terlihat penggunaan alat kontrasepsi modern terbesar di kedua provinsi pada wanita yang sudah mempunyai anak lengkap, laki-laki dan perempuan. Ini menunjukkan wanita yang berpotensi memakai alat kontrasepsi modern adalah wanita yang mempunyai anak dengan komposisi lengkap dan ada kecenderungan wanita untuk mempunyai anak dengan komposisi lengkap. Hal ini sejalan dengan temuan bahwa komposisi jenis kelamin anak merupakan faktor dominan dalam menentukan jenis alat kontrasepsi (Aryati, 2019). 
Tabel 2. Distribusi Persentase Penggunaan Alat Kontrasepsi Modern menurut Karakteristik Responden di Provinsi Sumatera Utara dan Jawa Tengah

\begin{tabular}{|c|c|c|c|c|}
\hline \multirow[b]{2}{*}{ Variabel } & \multicolumn{2}{|c|}{ Sumatera Utara } & \multicolumn{2}{|c|}{ Jawa Tengah } \\
\hline & $\begin{array}{c}\text { Menggunakan } \\
\text { kontrasepsi modern }\end{array}$ & Tidak & $\begin{array}{c}\text { Menggunakan } \\
\text { kontrasepsi modern }\end{array}$ & Tidak \\
\hline \multicolumn{5}{|l|}{ Komposisi Jenis Kelamin AMH } \\
\hline Laki-laki semua & 32,5 & 67,5 & 56,9 & 43,1 \\
\hline Perempuan semua & 31,7 & 68,3 & 57,0 & 43,0 \\
\hline Laki-laki dan perempuan & 53,1 & 46,9 & 66,0 & 34,0 \\
\hline \multicolumn{5}{|l|}{ Jumlah AMH } \\
\hline AMH 1 anak & 16,7 & 81,3 & 48,4 & 51,2 \\
\hline AMH 2 anak & 46,7 & 53,3 & 67,2 & 32,8 \\
\hline AMH 3-4anak & 53,5 & 46,5 & 65,6 & 34,4 \\
\hline AMH lebih dari 4 anak & 51,1 & 48,9 & 49,4 & 50,6 \\
\hline \multicolumn{5}{|l|}{ Status Bekerja } \\
\hline Bekerja & 42,3 & 57,7 & 58,0 & 42,0 \\
\hline Tidak Bekerja & 47,8 & 52,2 & 64,5 & 35,5 \\
\hline \multicolumn{5}{|l|}{ Kelompok Umur } \\
\hline 15-19 tahun & 26,7 & 73,3 & 65,4 & 34,6 \\
\hline 20-34 tahun & 42,2 & 57,8 & 62,2 & 37,8 \\
\hline 35 tahun ke atas & 46,0 & 54,0 & 59,6 & 40,4 \\
\hline \multicolumn{5}{|l|}{ Keinginan Mempunyai Anak } \\
\hline \multicolumn{5}{|l|}{ Lagi } \\
\hline Lainnya & 43,2 & 58,8 & 56,6 & 43,4 \\
\hline Tidak ingin punya anak lagi & 45,2 & 54,8 & 63,8 & 36,2 \\
\hline
\end{tabular}

Di Sumatera Utara wanita yang hanya mempunyai anak laki-laki lebih banyak menggunakan kontrasepsi modern dibandingkan wanita yang hanya mempunyai anak perempuan. Sedangkan di Jawa Tengah persentase penggunaan alat kontrasepsi pada wanita yang hanya mempunyai anak laki-laki dan hanya mempunyai anak perempuan hampir sama.

Hal ini mungkin terjadi karena di Sumatera Utara terdapat preferensi terhadap anak laki-laki-laki, sehingga jika tidak mempunyai anak laki-laki akan lebih kecil keinginan untuk menggunakan alat kontrasepsi dibandingkan jika tidak mempunyai anak perempuan. Tambunan (2007) menyatakan kehadiran anak laki-laki dalam suatu keluarga masih merupakan keharusan dan mutlak dengan alasan sebagai penerus marga dari bapaknya. Hal ini menyebabkan preferensi terhadap anak laki-laki lebih besar dibandingkan anak perempuan.
Apabila dilihat menurut jumlah anak masih hidup yang dimiliki, semakin banyak jumlah anak maka persentase penggunaan alat kontrasepsi semakin besar. Hal ini mungkin karena responden sudah merasa cukup dengan jumlah anak yang dimiliki.

Menurut Indraswari (2017).Status bekerja wanita akan berpengaruh terhadap fertilitas. Jika dilihat dari status bekerja, di kedua provinsi persentase penggunaan alat kontrasepsi modern lebih besar pada wanita yang tidak bekerja. Ini tidak sejalan dengan penelitian Palamuleni (2013) yang menemukan wanita yang tidak bekerja mempunyai kecenderungan untuk menggunakan alat kontrasepsi 1,26 kali lebih rendah dibandingkan wanita yang bekerja.

Hasil penelitian ini menemukan di Sumatera Utara, wanita yang tidak menginginkan anak lagi ternyata pemakaian alat kontrasepsinya tidak mencapai 50 persen. Padahal, 
menurut Asiimwe (2013) keinginan menambah atau tidak menambah anak lagi berhubungan signifikan dengan penggunaan kontrasepsi.

d. Analisis Model Regresi Logistik Biner

Uji keberartian model dilakukan dengan menggunakan statistik uji $\mathrm{G}$. Output $\mathrm{G}=-2 \log$ likelihood sebesar 2.303,127 pada model 1 dan $-2 \log$ likelihood sebesar 6.340,515 pada model 2, dengan tingkat kepercayaan sebesar 95 persen. Karena nilainya lebih besar dari $\mathrm{X} 2$ tabel $\left(\mathrm{X}^{2}\right.$ tabel $=$ 16,918) maka ini mengindikasikan bahwa model adalah signifikan. Hasil hitung omnibust test menunjukkan angka chi square model sebesar 167,814 pada model 1 dan 231,343 dan nilai signifikansi p sebesar 0,000 . Karena nilai signifikansi chi-square goodness of fit lebih kecil dari 0,05, ini mengindikasikan bahwa model adalah signifikan.

Dari hasil analisis didapatkan nilai odds ratio yang merupakan rasio peluang yaitu peluang menggunakan alat kontrasepsi modern per peluang tidak menggunakan alat konrasepsi modern. Nilai ini bisa digunakan sebagai nilai yang menunjukkan besarnya pengaruh perubahan independen terhadap variabel dependen.

Di Sumatera Utara, wanita yang mempunyai anak perempuan saja, peluang memakai alat/cara kontrasepsi. Peluang wanita untuk menggunakan alat kontrasepsi modern pada wanita yang hanya mempunyai anak perempuan saja lebih kecil 0,688 kali dibandingkan wanita yang mempunyai anak lakilaki saja. Akan tetapi, wanita yang

Tabel 3. Koefisien Regresi Logistik, Statistik Uji Wald, Signifikansi, dan Odds Ratio dari Pengaruh Variabel terhadap Penggunaan Alat Kontrasepsi Modern di Sumatera Utara dan Jawa Tengah

\begin{tabular}{|c|c|c|c|c|c|c|c|c|}
\hline \multirow[b]{2}{*}{ Variabel } & \multicolumn{4}{|c|}{ Sumatera Utara } & \multicolumn{4}{|c|}{ Jawa Tengah } \\
\hline & $\mathrm{B}$ & Wald & Sig. & OR & $\mathrm{B}$ & Wald & Sig. & OR \\
\hline Constant & 0,196 & 1.280 & 0,258 & 1,217 & 0,172 & 0,590 & 0,443 & 1,188 \\
\hline \multicolumn{9}{|l|}{$\begin{array}{l}\text { Komposisi Jenis Kelamin } \\
\text { AMH }\end{array}$} \\
\hline Laki-laki semua & & Ref & & & & Ref & & \\
\hline Perempuan semua & $-0,375$ & 5,850 & 0,016 & 0,688 & $-0,054$ & 0,358 & 0,549 & 0,947 \\
\hline Laki-laki dan perempuan & $-0,318$ & 3,698 & 0,054 & 0,727 & $-0,058$ & 0,419 & 0,518 & 0,943 \\
\hline \multicolumn{9}{|l|}{ Jumlah AMH } \\
\hline AMH 1 anak & & Ref & & & & Ref & & \\
\hline AMH 2 anak & $-1,707$ & 44,033 & 0,000 & 0,181 & $-0,435$ & 3,112 & 0,078 & 0,647 \\
\hline AMH 3-4anak & $-0,273$ & 2,009 & 0,156 & 0,761 & 0,571 & 6,269 & 0,012 & 1,770 \\
\hline AMH lebih dari 4 anak & 0,037 & 0,048 & 0,826 & 1,038 & 0,602 & 6,913 & 0,009 & 1,827 \\
\hline \multicolumn{9}{|l|}{ Status Bekerja } \\
\hline Bekerja & $-0,335$ & 9,100 & 0,003 & 0,716 & $-0,249$ & 15,290 & 0,000 & 0,780 \\
\hline \multirow[t]{2}{*}{ Tidak Bekerja } & & Ref & & & & & & \\
\hline & & & & \multicolumn{5}{|c|}{ Ref } \\
\hline \multicolumn{9}{|l|}{ Kelompok Umur } \\
\hline 15-19 tahun & & Ref & & & & Ref & & \\
\hline 20-34 tahun & 0,381 & 2.859 & 0,530 & 1,463 & 1.008 & 5,772 & 0,016 & 2,741 \\
\hline 35 tahun ke atas & 0,199 & 0,395 & 0,099 & 1,220 & 0,609 & 57,132 & 0,000 & 1,839 \\
\hline \multicolumn{9}{|l|}{ Keinginan Mempunyai } \\
\hline \multicolumn{9}{|l|}{ Anak Lagi } \\
\hline Lainnya & & Ref & & & & Ref & & \\
\hline Tidak ingin punya anak lag & 0,486 & 17,006 & 0,000 & 1,625 & $-0,078$ & 1,018 & 0,313 & 0,925 \\
\hline
\end{tabular}


mempunyai anak dengan komposisi laki-laki dan perempuan, peluang untuk menggunakan alat kontrasepsi modern tidak berbeda secara signifikan dibandingkan yang hanya mempunyai anak laki-laki. Hal ini mungkin karena masih kuatnya budaya patrilineal yang cenderung dominan di Sumatera Utara, sehingga memiliki preferensi yang lebih besar terhadap laki-laki, sehingga seorang wanita yang belum mempunyai anak laki-laki akan berusaha untuk mempunyai anak lagi sehingga tidak mau menggunakan alat kontrasepsi modern.

Di Jawa Tengah terjadi perbedaan dari hasil analisis. Wanita dengan semua komposisi jenis kelamin baik yang hanya mempunyai anak laki, anak perempuan, maupun yang sudah mempunyai anak lakilaki dan perempuan tidak berbeda signifikan dalam hal peluang penggunaan alat kontrasepsi modern. Sepertinya tidak ada preferensi terhadap jenis kelamin tertentu pada wanita di Jawa Tengah.

Mungkin di sini dapat dikatakan bahwa di Sumatera Utara son preference karena faktor budaya masih terjadi dan menunjukkan masih adanya nilai lebih pada anak laki-laki dibandingkan anak perempuan. Hal ini sejalan dengan Sumartini (2016) yang mengatakan bahwa faktor yang memengaruhi partisipasi PUS mengikuti program $\mathrm{KB}$ adalah masih rendahnya pengetahuan tentang $\mathrm{KB}$, sosial budaya masyarakat, dan cara untuk mengakses pelayanan KB. Aryati (2019) juga mengatakan bahwa komposisi jenis kelamin anak merupakan faktor dominan dalam menentukan jenis alat kontrasepsi.

Di Sumatera Utara, peluang untuk memakai alat kontrasepsi tidak berbeda secara signifikan kecuali pada wanita yang memiliki jumlah anak 2, peluangnya 0.181 lebih kecil untuk menggunakan alat kontrasepsi dibandingnya yang mempunyai anak 1 orang. Akan tetapi, di Jawa Tengah, wanita yang mempunyai 2 orang anak mempunyai peluang yang menggunakan alat kontrasepsi yang tidak berbeda secara signifikan dengan wanita yang hanya mempunyai 1 anak, dan peluang yang besar untuk menggunakan alat kontrasepsi pada wanita yang mempunyai anak 3-4 orang serta pada wanita yang mempunyai anak lebih dari 4.

Baik di Sumatera Utara maupun Jawa Tengah wanita yang bekerja mempunyai peluang untuk memakai alat kontrasepsi lebih kecil secara signifikan dibandingkan wanita yang tidak bekerja. Di Sumatera Utara, pada wanita yang bekerja, peluang menggunakan alat kontrasepsi 0,716 kali dibandingkan wanita yang tidak bekerja, sedangkan di Jawa Tengah peluangnya 0,780 kali. Hal ini tidak sesuai dengan hipotesis sebelumnya yang menyatakan bahwa wanita yang bekerja peluang menggunakan alat kontrasepsi lebih besar. Hal ini mungkin terjadi karena wanita yang bekerja cenderung memiliki kemampuan membiayai anaknya sehingga tidak melakukan pembatasan kelahiran dengan menggunakan alat kontrasepsi modern.

Berdasarkan umur responden, peluang menggunakan alat kontrasepsi di Sumatera Utara tidak berbeda secara signifikan bagi semua umur, baik wanita yang berumur 1519 tahun, 20-34 tahun, maupun yang berumur 35 tahun ke atas. Penelitian ini sesuai dengan penelitian Fitri pada tahun 2012 dan juga sejalan dengan Arifuddin pada tahun 2013 yang menyatakan tidak ada hubungan yang bermakna antara jumlah anak dengan pemilihan kontrasepsi. 
Berbeda dengan di Jawa Tengah, peluang menggunakan alat kontrasepsi dibandingkan pada wanita yang berumur 15-19 tahun, pada wanita yang berumur 20-34 tahun sebesar 2,741 kali, sedangkan pada wanita yang berumur 35 tahun ke atas peluangnya sebesar 1,839 kali.

Keinginan seorang wanita untuk menambah anak juga mempengaruhi penggunaan alat kontrasepsi. Di Sumatera Utara, wanita yang tidak menginginkan anak mempunyai peluang untuk menggunakan alat kontrasepsi 1,625 kali lebih besar dibandingkan wanita kategori lainnya. Akan tetapi, di Jawa Tengah, variabel ini tidak signifikan. Hal ini mungkin berkaitan juga dengan anak ideal yang diinginkan. Jika seorang wanita sudah mempunyai sejumlah anak yang diinginkan, maka besar kemungkinan dia tidak menginginkan mempunyai anak lagi.

\section{KESIMPULAN}

a. Komposisi jenis kelamin anak masih hidup yang dimiliki oleh wanita berpengaruh terhadap penggunaan kontrasepsi modern di Sumatera Utara.

b. Pada wanita yang belum mempunyai anak dengan komposisi jenis kelamin yang lengkap, peluang menggunakan alat kontrasepsi modern lebih besar pada wanita yang hanya mempunyai anak laki-laki saja dibandingkan wanita yang hanya mempunyai anak perempuan.

c. Di Jawa Tengah, komposisi jenis kelamin anak tidak berpengaruh secara signifikan terhadap penggunaan alat kontrasepsi modern.

d. Dari hasil temuan penelitian ini dimungkinkan karena masih adanya pengaruh faktor budaya yaitu adanya sex preference di Sumatera Utara, sedangkan di Jawa Tengah tidak ada sex preference. e. Selain komposisi jenis kelamin, variabel lain yang berpengaruh terhadap pemakaian alat kontrasepsi modern di Sumatera Utara adalah status wanita bekerja dan keinginan untuk mempunyai anak lagi.

f. Di Jawa Tengah, selain komposisi jenis kelamin, jumlah anak masih hidup, status wanita bekerja, dan kelompok umur berpengaruh terhadap penggunaan alat kontrasepsi modern.

\section{SARAN}

a. Adanya indikasi sex preference di Sumatera Utara mempunyai kecenderungan menjadi penghambat bagi penurunan tingkat fertilitas sehingga perlu peningkatan KIE tentang program $\mathrm{KB}$ untuk membentuk keluarga kecil berkualitas dengan semboyan dua anak cukup, lakilaki dan perempuan sama saja.

b. Son preference juga bisa menimbulkan peluang terjadinya perbedaan perlakuan terhadap anak laki-laki dan perempuan sehingga perlu ditingkatkan lagi informasi mengenai persamaan kedudukan anak laki-laki dan perempuan sehingga bisa tercapai kesetaraan gender.

\section{REFERENSI}

Adioetomo, S.M, Burhan, L, dan Yunus, N 2010, 100 Tahun Demografi Indonesia: Mengubah Nasib Menjadi Harapan, (Cetakan kedua). Jakarta: BKKBN dan LD FEUI

Ananta,A et al 2015 Demography of Indonesia's ethnicity, Singapura: Institute of Southeast Asian Studies Aryati, Seri , dkk 2019, 'Faktor-Faktor yang Mempengaruhi Pemilihan Metode Kontrasepsi (Kasus di Kecamatan Seberang Ulu I Kota Palembang), Majalah Geografi Indonesia, vol. 33, no. 1. doi: 10.22146/mgi.35474. 
Asih, L dan Oesman, H, 2018, 'Analisa Lanjut SDKI 2007: Faktor yang mempengaruhi pemakaian kontrasepsi jangka panjang (MKJP)', Puslitbang KB dan Kesehatan Reproduksi Badan Koordinasi Keluarga Berencana Nasional

Asmanedi, Simanjuntak, Z.A, Ahsan, A 2016, Kebijakan kependudukan dan tantangannya, Dalam Ari Kuncoro, Sonny Harry B Harmadi (Ed). Mozaik Demografi: Untaian Pemikiran tentang Kependudukan dan Pembangunan. Jakarta: Salemba Empat

Asiimwe, J.B dkk, 2013. 'SocioDemographic Factors Associated with Contraceptive Use among Young Women in Comparison with Older Women in Uganda', DHS Working Paper 2013, No. 95. ICF International: Calverton, Maryland, USA.

Bongaarts, J 2011, 'Fertility and reproductive in Post-Transitional Societies, Population and Development Review, Vol 27, Supplement: Global Fertility Transition (2001), pp. 260-281

BPS, BKKBN, Kemenkes, dan USAID 2018, Survei Demografi dan Kesehatan Indonesia 2017, Jakarta, Indonesia: BPS, BKKBN, Kemenkes, and USAID

Burhan, L 2010, Kebijaksanaan kependudukan dan keluarga berencana (suatu rekayasa demografi membangun bangsa), (Cetakan kedua). Jakarta: BKKBN

Calhoun,L.M et al 2001 'Does sex preference affect contraceptive use in Bangladesh?', International Quartely of Community Health Education, 2000/2001, 20, 4, pg. 381

Calhoun,L.M et al 2013 'The effect of family sex composition on fertility desires and family planning behaviours in urban Uttar Pradesh, India', Reproductive Health., 10:48
Durlauf, S.N. dan Walker, J.R. 1999, 'Fertility and reproductive in PostTransitional Societies, Working papers 28, Wisconsin Madison Social Systems

Freedman, R. 1974 Cross cultural comparisons : data on two factors in fertility behavior, The Population Council

Freedman, R. 1975 The Sociology of Human Fertility, New York: Irvington

Hosmer, D. W. dan Lemeshow, S 2000, Applied Logistic Regression, John Willey \& Sons, New York.

Indraswari, Risa R dan Yuhan, Risni J, 2017, 'Faktor-faktor yang Memengaruhi Penundaan Kelahiran Anak Pertama I Wilayah Perdesaan Indonesia: Analisis Data SDKI 2012', Jurnal Kependudukan Indonesia, vol. 12, no. 1 Juni 2017. 1-12

Kabir, A, Islam, M.S, dan Kabir, M, 2001 'Does sex preference affect contraceptive use in Bangladesh?', International Quartely of Community Health Education, 2000/2001, 20, 4, pg. 381

Kementerian Kesehatan Republik Indonesia 2015 Profil Kesehatan Indonesia Tahun 2014, Jakarta: Kementerian Kesehatan RI

Koentjaraningrat. 1971 Manusia dan kebudajaan di Indonesia, Jakarta: Djambatan

Musdalifah, Sarake, M, dan Rahma 2013, 'Faktor yang Berhubungan dengan Pemilihan Kontrasepsi Hormonal Pasutri di Wilayah Kerja Puskesmas Lampa Kecamatan Duampanua Kabupaten Pinrang 2013', Makassar:Universitas Hasanuddin

Palamuneni, 2013. 'Socio-economic and Demographic Factors Affecting Contraceptive Use in Malawi', African Journal of Reproductive Health, Vol. 17, No. 3 (September 2013), pp. 91104 
Sumartini dan Indriani, Diah, 2016, 'Pengaruh Keinginan Pasangan Usia Subur (Pus) dalam Penggunaan Metode Kontrasepsi Jangka Panjang', Jurnal Biometrika dan Kependudukan, vol. 5 no. 1 Juli 2016. 27-34

United Nations 2015, World population prospects the 2015 revision: Key finding and advance tables, New York: Department of Economic and Social Affairs Population Division. Retrieved from: esa/publications/world-populationprospects-2015-revision.

Tambunan, M, 2007 . 'Perubahan fungsi dan makna anak kali-laki pada komunitas Batak Toba-Kristen: Suatu kajian antropologis pada masyarakat Desa Cinta Damai Kecamatan Percut Sei Tuan', Journal 21460 Antropologi, Vol. 4 No. 1 Okt 2007

https://www.un.org/en/development/d 